Gunderson, J. \& SABO, A. (1993) The phenomenal and conceptual interface between borderine personality disorder and PTSD. American Joumal of Psychiatry. 160. 19-27.

Guthrese, E. Crebed, F. Dawson, D. 2 Tomenson, B. (1991) A controlled trial of poychological treatment for the irritable bowel syndrome. Gastroenterology, 100, 450 457.

Higartr. A. \& Fonnay, P. (1992) Psychotherapy in borderline and narcissistic personality disorder. Brttish Joumal of Psychiatry, 161, 23-41.

Holmes, J. (1991) (ed.) A Textbook of Psychotherapy in Psychlatric Practice. Edinburgh: Churchill Livingstone.

- (1992) Between Art and Sclence: essays in psychotherapy and psychiatry. London: Routledge.

LEFT, J. (1994) Working with the familles of schizophrenic patients. Brttish Joumal of Psychiatry, 164 (suppl. 23), 71-76.

MAPX, K. \& Engels, F. (1847) The Communist Manifesto. London: Lawrence \& Whathart.
MORGAN, G. (1994) How feasible is suicide prevention? Current Opinion in Psychiatry, 7, 111-118.

STEVENSON, J. \& MEARES, R. (1992) An outcome study of poychotherapy for patients with borderline personality disorder. American Joumal of Psychiatry, 149, 358-362.

WhLLRESTEN, R. (1986) Forty Two Lwes in Treatment: a study of psychoanalysis and psychotherapy. New York: Guilford.

Winston, A. PINSKER, H. \& MCCULUUGH, L. (1986) A review of supportive psychotherapy. Hospital and Communtty Psychiatry, 37, 1105-1114.

Jeremy Holmes, Consultant Psychiatrist/ psychotherapist, North Devon District Hospital, Barnstaple, Devon EX31 4JB; and Sally Mitchison, Senior Registrar, Stanley Royd Hospital, Wakefield, Yorkshire WF1 4DQ

\title{
Animals, humans and Martians: the concept of persons
}

\author{
Femi Oyebode
}

This paper examines the concept of the person as ditinct from the concept of the human being. If argues that the citterle which some contemporary phillosophers propose for making this ditinction are likely to hove cotverse effects for the moral status of people with lecuning discbility and poychiatilic disorders respectively.

The concept of the person as distinct from the concept of the human being has emerged from the moral problems posed to clinicians and moral philosophers by dilemmas in at least three separate areas, namely abortion, withdrawal of life-saving or sustaining treatments, and the attempt by some philosophers to forge a description of what animal rights consists of. In addition, there is the task as some philosophers see it, of providing a framework that would in principle enable us to answer the question "are there other people in the universe?" (Harris, 1985). Much of this literature is concerned with the exploration of criteria that determine personhood and by implication moral value. In this paper I will examine the arguments put forward for adopting particular criteria for assigning the status of person to some humans and not to others and then go on to argue that there is no compelling reason to make such a distinction between 'persons' and 'human beings'. Indeed. such a distinction is likely to have deleterious effects upon the moral status of people with learning disability and psychiatric disorders respectively. 


\section{Persons are valuable}

Some contemporary philosophers such as Harris (1985) use the term 'person' to stand for "any being who has what it takes to be valuable". He goes on to say that "when we ask what makes human life valuable we are trying to identify those features whatever they are, which both incline us and entitle us to value ourselves and one another". And the purpose of identifying these features, in part, is to enable us to distinguish persons from nonpersons. For Harris, only persons have the "sort of value and importance that makes appropriate and justifies our according to them the concern, respect and protection as we grant to one another". Language is seen as the definitive evidence of personhood because it is the hallmark of self-consciousness; "any creature with even the most rudimentary form of language will be able to let us know that it values life and wants to go on living". The preeminence of language in his scheme dertves from the Lockean description of a person as a "thinking intelligent being, that has reason and reflection and can consider itself the same thinking thing, in different times and places; which it does by that consciousness which is separable from thinking" (Locke, 1690). I suppose that for Harris, language is an expression of reason, self-consciousness and much else and will do as a marker for what makes human life valuable. His aim is to give "an account of why humans are valuable apart from the fact that they are human". This account which Harris offers leads inexorably to the conclusion that some human beings are not persons and that therefore their lives do not matter, morally speaking.

Unlike Harris, Tooley (1986) believes that self-consciousness rather than language, "the concept of the self as a continuing subject of experiences, and which believes that it is itself such an entity" is a necessary condition for having a serious right to life. Put in another way, having a right to life presupposes that one is capable of desiring to continue to exist as a subject of experiences and other mental states. Following from this, human foetuses and infants do not satisfy the conditions necessary for personhood, thus they do not have a right to life.

This conclusion, that some human beings may not have a right to life, in Tooley's schema, may be avoided if mere consciousness rather than self-consciousness was the criterion for personhood. It would then form the basis for extending the right to life to infants, severely mentally handicapped individuals and animals. However, some philosophers believe that this feature is too all-inclusive because it would include most humans such that it would serve no practical purpose; it is therefore rejected as a basis for distinguishing between persons and nonpersons (Singer, 1993). In other words, the philosophical project is to distinguish between 'persons' and 'human beings' such that for example some non-human animals may come to be regarded as persons who have a right to life while some human beings, newborn infants and those with severe mental retardation, will be designated as 'nonpersons' and will not have this kind of right to life.

The positions of Harris, Tooley, and Singer respectively are variations on the same theme. The core notion is that personhood is determined by the possession of either language or self-consciousness or some such feature. The underlying assumption is that it is possession of a particular feature such as this that certifies the moral value of a particular human being. In other words, that mere inclusion in the class "human being is irrelevant, morally speaking. These characteristics that are being proposed are not without problems. There is no reason to suppose that a right-handed individual who has suffered a cerebrovascular accident with consequent damage to both Broca's and Wernicke's areas and resultant expresstve and receptive aphasia is substantially different in kind compared with any other person. Language is only one of the functions of the brain. Damage to that function is compatible with preservation of several other functions that are peculiarly human in nature such as appreciation and composition of music, recognition of faces and the capacity to recognise emotions. The possession of language or indeed of any of the other capacities listed above, in my view, is not a relevant factor in determining moral value.

In much the same way, self-consciousness as defined by Tooley (1986) is only one out of several faculties of the mind. Patients who suffer bilateral damage to the mamillary bodies or hippocampus do not retain any new information and arguably do not have a true notion of themselves as beings living in time. It could be argued that their notion of self is composed entirely of a self made up of memory up to the point of damage to the brain. 
However, these individuals continue to exhibit all other characteristics of humans. They continue to have the capacity to value life. In addition, some individuals with damage to the right parietal lobes are unable to recognise that their limbs are theirs and in cortical blindness are unable to percetve even though their eyes are clearly able to accommodate to light; these are examples of part loss of self-consciousness. These individuals continue to demonstrate all other human characteristics without fail and are in my view proper recipients of our moral concern.

\section{The importance of being human}

There are other contemporary philosophers like Diamond (1991) who argue in opposition to Harris, Tooley and Singer. Diamond, for example, argues that "having a human life to lead is made in imagination, and is reflected in the doings and customs of those who share having a human life to lead". She goes on to say "there is a possibility of deep moral concern for retarded people in which they are seen as having, however incomprehensible we may find it, a human fate, as much as anyone else.... They are seen with us in being human, where that is understood not in a biological sense, but imaginatively". Diamond's concern is not to locate personhood or humanity in particular features, but rather to emphasise that the notion 'human being' has a significant place in moral thought simply by our capacity to imagine the other as belonging to the sphere of our concern. Although she does not say so openly, human culture in all its variety, in the sense in which it is the product of our creative imagination is the basis of this "feeling of unavoidable solidarity in mysterious origin, in hope, in uncertain fate which binds all men to each other and all mankind to the visible world" (Conrad, 1897). There is no easily definable criterion here for those who wish to determine whose life is valuable by a simple set of instructions. In response to critics, Diamond answers "I have been asked what it means to say of a severely retarded person that he or she has a human life to lead. I do not mean by 'having a human life to lead' having a life in which distinctively human capacities are exercised. Someone may be deprived, for part or all of his life, of distinctively human capacities like reason. Human life without the exercise of those capacities is his human life. The one human life he is given has that terrible deprivation".

Diamond's position has the advantage that it eschews any categorisation of human beings into 'persons' and 'non-persons' on the basis of certain criteria which give the spurious air of precision in an arena where that kind of precision is not needed or helpful. Her account implies that our moral status is bestowed upon us by other members of our community rather than held by us by virtue of what we are. While this might at first sight appear as if our humanity is bestowed like a gift upon us by others, rather than as something we can claim because of our characteristics, the fact is that we learn at an early age that we are regarded as part of the human community before we can lay claim to this as a valid description of ourselves. The status 'human being' or 'person' is conferred by others in recognition of the fact that we are like them. This is what Martin Buber (1937) means when he says "man becomes an I through a You".

The charge of speciesism has been levied at this kind of account that attributes human value simply to the fact of belonging to the human species. This is likened to racism and sexdsm. This charge is difficult to counter. Nonetheless it is true that if a choice had to be made between kdlling a person or a dog, most people would probably opt to kdll the dog and as Warnock (1983) puts it "if someone did not prefer to save a human rather than a dog or a fly, we would think him in need of justification.... To live in a universe in which we were genuinely species-indifferent would be impossible, or if not impossible, then in the highest degree undesirable". The features that distinguish human beings from other animals do not appear to underlie why we value human beings more; we value other human beings more, simply because they are human.

Whether animals or Martians can legitimately be deemed persons at present is another matter. Strictly speaking, the use to which words can be put is infinite. However, if either is so described it would require a radical change in the use of the term and our understanding of the duties and obligations which flow from being a member of the class 'person' would probably alter. 


\section{Persons as human beings}

The attempts to locate moral value in particular features rather than simply in being a member of the class 'human being' have grave dangers attached to them. The greatest risk is that moral value becomes linked to irrelevant features such as language, self-consciousness, capacity to express life plans, etc. The moral value of all human beings, irrespective of defects, age (including foetuses), should be regarded as equal. The capacity to be moral agents, i.e. to act rationally and to be responsible for the consequences of actions is dependent upon certain cognittve features. However, moral value is not determined by the capacity to be a moral agent.

I do not find the arguments for distinguishing persons and human beings compelling. Indeed, the conclusions which Harris, Tooley and Singer reach from their respective positions are repugnant precisely because they treat certain persons as nonpersons. The implications of their views for the status of mentally handicapped individuals, brain damaged individuals, some psychiatric patients, children and infants are far reaching. Much has been gained in this century in improving the position of many of these groups in society. The arguments put forward by Harris, Tooley and Singer respectively are likely to damage the gains already made.

In the abortion debate, or in the debate about withdrawal of treatments, the notions of personhood do not add very much more to the discussions. There are already other approaches that do not carry the same dangers. In abortion, notions about viability and development of pain perception can be more persuastve and in the area of withdrawal of treatments, the futility of medical treatment or some such notion is a more worthwhile one. Regarding issues about animal rights, there is no need to invoke the idea that some human beings are not persons and therefore have no right to life to make the point that animals deserve to be well treated. In short I believe that the notion of personhood is being asked to do more work than it can bear.

\section{References}

BUBer, M. (1937) I and Thou (trans W. Kaufmann). New York: Scribners.

CONRAD, J. (1897) The Nigger of Narclssus. London: Harmondsworth

DIAMOND. C. (1991) The importance of being human. In Human Betng (ed. D. Cockburn). pp. 35-62. Cambridge: Cambridge Untversity Press.

HARRIS, J. (1985) The Value of Lfe. London: Routledge.

LOCKE. J. (1690) An Essay Concerning Human Understanding. London: Dent.

Singer, P. (1993) Antmals and the value of life. In Matters of Lufe and Death (ed. T. Regan), pp. 280-321. New York: McGraw-Hill.

TooLEY, M. (1986) Abortion and infanticlde. In Applied Ethics (ed. P. Singer). pp. 57-85. Oxford: Untversity Press.

WARNOCK. M. (1983) In vttro fertilization: the ethical issues (II). The Philosophical Quarterly, 3s, 238-249.

Femi Oyebode, Consultant Psychiatrist and Senior Clinical Lecturer, Queen Elizabeth Psychiatric Hospital, Mindelsohn Way, Edgbaston, Birmingham B15 $2 Q Z$ 